\title{
Effect of weather factors on the population of Chaetocnema spp.,Monolepta signata Oliver and Aulacophora foveicollis (Lucas) on paddy under rainfed lowland conditions in Mizoram, India
}

\author{
T. BOOPATHI ${ }^{*}$ S.B. SINGH, T. MANJU, S.K. DUTTA, S. SAHA, A.R. SINGH, Y. RAMAKRISHNA², \\ SAMIK CHOWDHURY, LUNGMUANA, V. DAYAL and S.V. NGACHAN \\ ICAR Research Complex for NEH Region, Mizoram Centre, Kolasib-796081, Mizoram, India. \\ ${ }^{1}$ ICAR Research Complex for NEH Region, Umroi Road, Umiam-793103, Meghalaya, India. \\ ${ }^{2}$ Krishi Vigyan Kendra, Ukhrul District, Manipur-795145 \\ *Corresponding authorE-mail: boopathiars@gmail.com
}

\begin{abstract}
The present study was undertaken during kharif 2013 and 2014 to know the relationship between weather parameters and chrysomelids (Coleoptera: Chrysomelidae)viz., Chaetocnema spp., Monolepta signata Oliverand Aulacophora foveicollis (Lucas)in rice agro-ecosystem in Mizoram, India.Chaetocnema spp., and $M$. signata were found to first invade the crop during last week of August, whereas $A$. foveicollis was recorded during third week of September. The highest populations of Chaetocnema spp. and M. signata were during September. However, the highest population of $A$. foveicollis was during October. Morning relative humidity $(\mathrm{RH})$ had significant correlation with populations of Chaetocnema spp., $M$. signata and $A$. foveicollis. When there was abrupt fall in minimum temperature and coupled with increase in morning $\mathrm{RH}$, rainfall and rainy days a build-up in Chaetocnema spp. population was recorded during the pooled year. These studies clearly indicate that weather factors play an important role in Chaetocnema spp., M. signata and $A$. foveicollis incidence.
\end{abstract}

Key words : Seasonal abundance, seasons, weather parameters, interaction, Eastern Himalayas, population buildup

Rice, the staple food of over half of the world's population, is grown in more than 110 countries. Most of the world's rice production is from irrigated and rainfed lowland rice fields where insect pests are constraints (Pathak and Khan, 1994). Rice is grown in the warm and humid environment which is also conducive to the proliferation of insects. Modern varieties, high tillering, heavily fertilized and the practice of multi-cropping rice throughout the year favors the buildup of pest populations. Average rice yield loss due to various insect pests was estimated to be $31.5 \%$ in Asia (excluding China) and $21 \%$ in North and Central America. The rice plant is subject to attack by more than 100 species of insects (Arora and Dhaliwal, 1996); 20 of them can cause economic damage. Together they infest all parts of the plant at all growth stages, and a few transmit viral diseases.

Climatic conditions largely influence the insect pests number and activity as well as several parasites and predators either directly or indirectly (Arif et al., 2006; Kumar and Gupta, 2016; Saha et al. 2016). Boopathi et al., (2012) have shown that besides the availability of new leaves and shoots, weather factors also play an important role in Chaetocnema spp., M. signata and A. foveicollis incidence.The pest status does not remain static throughout the year but changes accordingly based on weather factors. Therefore, a thorough understanding of interaction between weather parameters and pest dynamics is pre-requisite for weather-based pest forecasting model. Hence, the present study was undertaken to know the relationship between weather factors and chewing pests in rice agro-ecosystem in Mizoram, India.

\section{MATERIALS AND METHODS}

\section{Field experiment}

The present study was carried out at the research farm, ICAR Research Complex for NEH Region, Mizoram Centre, Kolasib, Mizoram, India during kharif season in both 2013 and 2014 with rice cultivar Gomati. Around 2000 $\mathrm{m}^{2}$ area was taken to study the population buildup of Chaetocnema spp., M. signata and A. foveicollis in lowland rice. The total area was divided into ten equal segments and 
considered each one as a replication. The rice crop was established by manual transplanting of 25 days old seedlings with spacing of $20 \times 10 \mathrm{~cm}$ row to row and plant to plant, respectively. All the recommended agricultural practices were followed in raising the crop. No plant protection measure was taken throughout the crop season.

Observations on the incidence of Chaetocnema spp., M. signata and A. foveicollis were recorded starting from initial appearance to up to harvest. Sampling was done at weekly interval accountinga dults of Chaetocnema spp., $M$. signata and A. foveicollis by counting number of beetles/ plant/hill from 10 randomly selected plants in 10 hills. The daily weather data for study period was obtained from the Meteorological Unit, ICAR Research Complex for NEH Region, Mizoram Centre, Kolasib, Mizoram, India.

\section{Data analysis}

The weekly data on chrysomelids incidences were subjected to correlation analyses with average weekly weather factors with pooled data of two years (2013 and 2014) to find out the influence of abiotic factors on insects infestation. Data were analyzed using two-way ANOVA for seasonal incidence of Chaetocnema spp., M. signata and $A$. foveicollis during two seasons.

\section{RESULTS AND DISCUSSION}

\section{Chaetocnema spp.}

The seasonal fluctuation of Chaetocnema spp. varied from $0.2 \pm 0.2$ to $16.3 \pm 3.1$ per 10 plants in the pooled data (average of 2013 and 2014) (Table 1). The population increased reaching a peak on $36^{\text {th }}$ standard meteorological week (SMW) i.e. first week of September( $16.3 \pm 3.1$ per 10plants).There was not significant difference in its population due to season/year, where as its population significantly varied due to weekly distribution (Table 2).

Correlation coefficient between Chaetocnema spp. population and weather factors revealed that Chaetocnema spp. population had positive significant correlation with morning $\mathrm{RH}(\mathrm{r}=0.831)$, rainfall $(\mathrm{r}=0.832)$ and rainy days $(\mathrm{r}=0.809)$ in the pooled data (Table 3$)$, while minimum temperature $(\mathrm{r}=-0.723)$ had negative significant correlation with Chaetocnema spp. population. Maximum temperature, evening RH and total EP showed non-significant correlation with Chaetocnema spp. population. Earlier, Boopathi et al. (2012) reported that Chaetocnema spp. had positive significant correlation with morning relative humidity. 
Table 2: Analysis of variance (ANOVA)

\begin{tabular}{|c|c|c|c|c|c|c|c|}
\hline \multirow[t]{2}{*}{ Source } & \multirow[t]{2}{*}{ df } & \multicolumn{2}{|c|}{ Chaetocnema spp. } & \multicolumn{2}{|c|}{ M. signata } & \multicolumn{2}{|c|}{ A. foveicollis } \\
\hline & & $F$ value & $P$ value & $F$ value & $P$ value & $F$ value & $P$ value \\
\hline Season $(\mathrm{S})$ & 1,30 & 0.056 & $0.815 \mathrm{~ns}$ & 1.171 & $0.288 \mathrm{~ns}$ & 0.042 & 0.839 \\
\hline Week $(\mathrm{W})$ & 7,30 & 11.676 & $<0.001$ & 6.754 & $<0.001$ & 5.354 & $<0.001$ \\
\hline Interaction $(\mathrm{S} \times \mathrm{W})$ & 7,30 & 0.770 & $0.616 \mathrm{~ns}$ & 0.469 & $0.849 \mathrm{~ns}$ & 0.912 & $0.511 \mathrm{~ns}$ \\
\hline
\end{tabular}

ns, non-significant.

Table 3: Correlation between weather parameters and population of Chaetocnema spp., Monolepta signata and Aulacophora foveicollison paddy under rainfed lowland condition (Pooled data of 2013 and 2014)

\begin{tabular}{llll}
\hline Weather parameters & Chaetocnema $\mathrm{spp}$. & M. signata & A. foveicollis \\
\hline Maximum temperature & $0.104 \mathrm{~ns}$ & $0.066 \mathrm{~ns}$ & $0.119 \mathrm{~ns}$ \\
Minimum temperature & $-0.723^{*}$ & $-0.007 \mathrm{~ns}$ & $0.608 \mathrm{~ns}$ \\
Morning relative humidity & $0.831^{*}$ & $0.720^{*}$ & $-0.793^{*}$ \\
Evening relative humidity & $0.377 \mathrm{~ns}$ & $0.537 \mathrm{~ns}$ & $-0.397 \mathrm{~ns}$ \\
Rainfall (mm) & $0.832^{*}$ & $0.328 \mathrm{~ns}$ & $0.840^{* *}$ \\
Rainy days (d) & $0.809^{*}$ & $0.444 \mathrm{~ns}$ & $-0.750^{*}$ \\
Total EP & $-0.351 \mathrm{~ns}$ & $0.031 \mathrm{~ns}$ & $0.034 \mathrm{~ns}$ \\
\hline
\end{tabular}

$\mathrm{ns},{ }^{*}, *$ non-significant or significant at $\mathrm{P} \leq 0.01$ or $\mathrm{P} \leq 0.05$

\section{Monolepta signata}

The seasonal fluctuation of $M$. signata varied from $1.0 \pm 0.8$ to $10.3 \pm 1.3$ (Table 1 ). There was two peaks in its population first peak during $36^{\text {th }} \mathrm{SMW}(10.0 \pm 2.8$ per 10plants) and second during $39^{\text {th }} \mathrm{SMW}(10.3 \pm 1.3$ per 10plants), there after it decreased. Boopathi et al. (2012) reported that M. signata population was found more during September (16.25 per 10 plants). As observed in case of Chaetocnema spp., the population of M. signataalso did not vary between the years, however, within the season, weekly variation was significant (Table 2). M. signata population had positive significant correlation with morning $\mathrm{RH}(\mathrm{r}=0.720)$ (Table 3$)$. However, other weather parameters showed non-significant correlation with $M$. signata population.

\section{Aulacophora foveicollis}

The seasonal fluctuation of $A$. foveicollis varied less in comparison to others pests (Table 1). The activity of pumpkin beetle started from third week of September and the population reached a peak on second week of October i.e. $42 \operatorname{SMW}(1.5 \pm 0.5$ per 10plants). In contrast to other two pests, the population of $A$. foveicollis varied significantly between the season/years as well as during the weeks (Table 2).
Correlation coefficient between A. foveicollis and weather factors revealed that $A$. foveicollis population had positive significant correlation with rainfall $(\mathrm{r}=0.840)$ (Table 3$)$, while morning $\mathrm{RH}(\mathrm{r}=-0.793)$ and rainy days $(\mathrm{r}=$ $-0.750)$ had negative significant correlation with pumpkin beetle population. However, other weather parameters showed non-significant correlation with pumpkin beetle population.

\section{REFERENCES}

Arif, M.J., Gogi, M.D., Mirza, M.,Zia, K. and Hafeez, F. (2006). Impact of plant spacing and abiotic factors on population dynamics of sucking pests of cotton. Pakistan J. Biol. Sci., 9:1364-1369.

Arora, R. and Dhaliwal, G.S. (1996). Agroecological changes and insect pest problems in Indian agriculture. Indian J. Ecol., 23:109-122.

Boopathi, T., Pathak, K.A., Ramakrishna, Y. and Verma, A.K. (2012). Influence of weather factors on the population dynamics of chewing pests of lowland paddy. Oryza, 49(3):200-204.

Kumar, M. and Gupta, A. (2016). Effect of weather variables on whitefly (Bemisia tabaci Gennadius) population in development of potato apical leaf curl virus disease. $J$. Agrometeorol.,18(2):288-291. 
Pathak, M.D. and Khan, Z.R. (1994). "Insect Pests of Rice”. International Rice Research Institute, Manila, Philippines.

Saha, S., Chakraborty, D., Singh, S. B., Chowdhury, S., Syiem, E. K., Dutta, S. K., Lungmuana, Choudhury B. U.,
Boopathi, T., Singh, A. R., Ramakrishna, Y. and Roy, A. (2016). Analyzing the trend in thermal discomfort and other bioclimatic indices at Kolasib, Mizoram. $J$. Agrometeorol.,18(1):57-61. 